This item was submitted to Loughborough's Research Repository by the author.

Items in Figshare are protected by copyright, with all rights reserved, unless otherwise indicated.

\title{
Nationalism, gender and the multivocality of war discourse in television news
}

PLEASE CITE THE PUBLISHED VERSION

http://dx.doi.org/10.1177/0163443711415745

PUBLISHER

(c) Sage

VERSION

AM (Accepted Manuscript)

LICENCE

CC BY-NC-ND 4.0

REPOSITORY RECORD

Pankov, Milos, Sabina Mihelj, and Veronika Bajt. 2019. "Nationalism, Gender and the Multivocality of War Discourse in Television News". figshare. https://hdl.handle.net/2134/8914. 
This item was submitted to Loughborough's Institutional Repository (https://dspace.lboro.ac.uk/) by the author and is made available under the following Creative Commons Licence conditions.

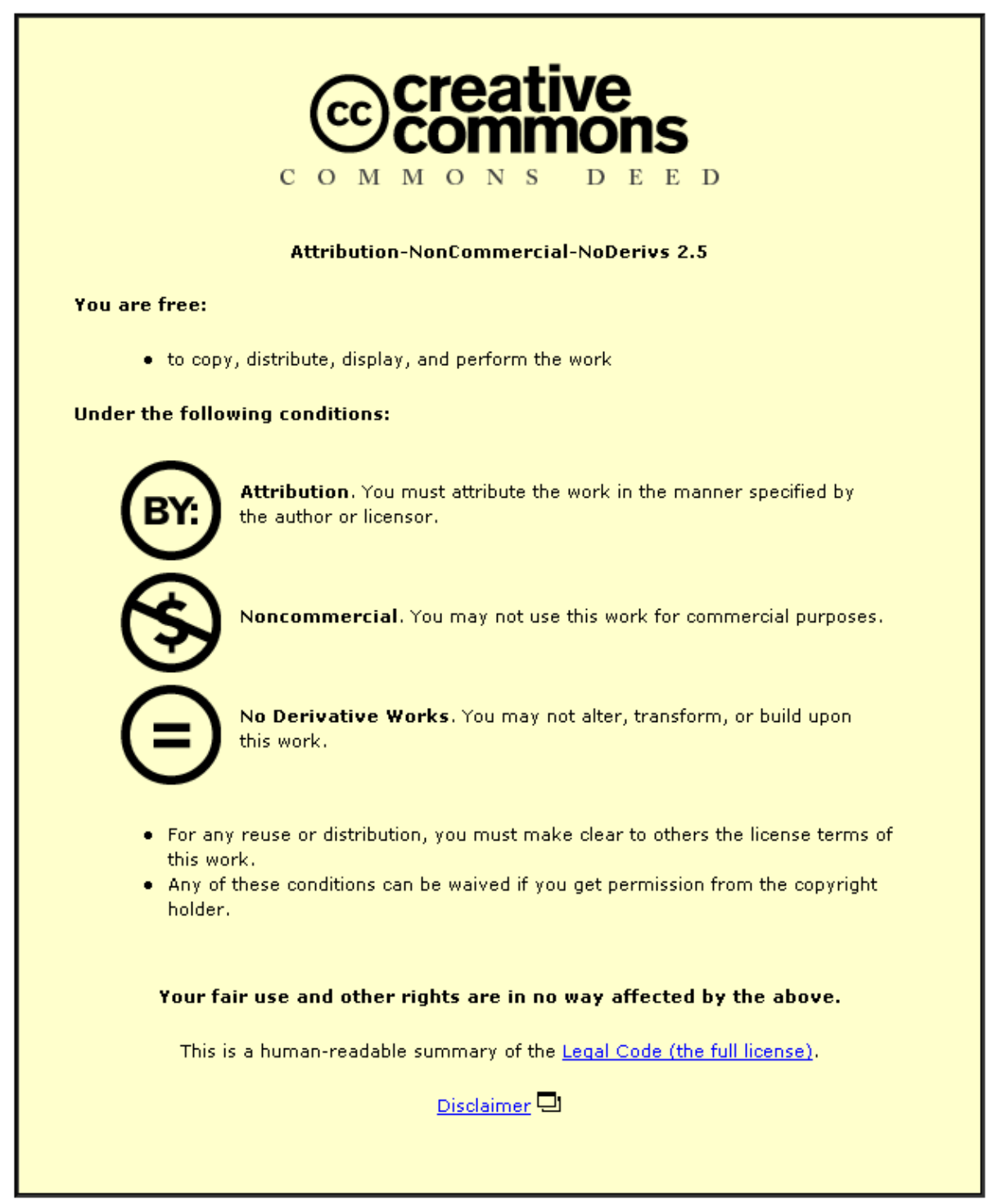

For the full text of this licence, please go to: http://creativecommons.org/licenses/by-nc-nd/2.5/ 
Date: March 2011, Version accepted for publication

\section{NATIONALISM, GENDER AND THE MULTIVOCALITY OF WAR DISCOURSE IN TELEVISION NEWS}

Milos Pankov, Sabina Mihelj and Veronika Bajt

The final, definitive version of this article has been published in Media, Culture and Society 33(7): 104359 (October 2011), by SAGE Publications Ltd, All rights reserved. (C [The Author]. Ulr:

http://online.sagepub.com.

\section{Introduction}

The presence of war is among the key contextual factors that can account for rapid changes in media discourse, including a shift from 'banal' to 'hot' forms of nationalism (Mihelj et al. 2009a). During periods of conflict, the usual democratic mechanisms regulating the production and circulation of public information are weakened, and the media are drawn into the promotion of social relations and values preferred by the ruling political structure (Van Dijk 2006: 15). These war-time relations and values typically involve a heightened emphasis on divisions between us - the goodies - and them - the baddies (Bugarski 1997, Mihelj et al. 2009b). Any other identities that a given person manifests, such as gender or age, are adapted to suit the polarizing logic of war discourse. In the case of gender, this leads to the rise of sexist forms of gendered discourse. The figure of the warrior, which plays a central role in war discourse, is typically associated with strength, aggressiveness and virility - all characteristics that are at odds with the archetypal 'feminine' qualities emphasized in the patriarchal gendered order (Prividera and Howard 2006: 29-30). Due to this, war coverage typically neglects or minimizes the contribution of women to the war effort, and pushes them into traditional, supportive roles of mothers and wives.

The mediated images of conflicts that broke out in the territory of the former Yugoslavia in the early 1990s followed this pattern. The rise of nationalist elites and the disintegration of the socialist federation went hand-in-hand with a redrawing of collective identities and media narratives. In domestic news coverage, markers of belonging to a wider Yugoslav 'we' were gradually replaced with unambiguous expressions of loyalty to a single Yugoslav nation - Slovenian, Serbian, Croatian etc. (Mihelj et al. 2009b). At the same time, the onset of the war also provoked the proliferation of 
traditional, patriarchal and heterosexual representations of women, centred on the figures of the woman-mother and the woman-victim (Milić 1993, Bracewell 1996, Žarkov 2007, Nikolić-Ristanović 2008). As a result, human beings appearing in media representations of the conflicts were not only ethnicized or nationalized, but always also gendered and sexualized.

Yet as argued in this paper, we should be wary of over-emphasizing the homogeneity of war discourse. While the onset of conflict certainly narrows the range of collective identities and narratives on offer in the public domain, it does not necessarily impose a total closure on the negotiation of meanings. Rather, mediated war discourse can, under certain circumstances, retain a measure of multivocality, which can be of vital importance to its appeal. We demonstrate this by examining a sample of war-time news bulletins broadcast in Yugoslavia in 1991, focussing on representations of women. We start by outlining the social and historical context relevant for our study, including the changing social position of women in socialist and post-socialist Yugoslavia and the key characteristics of the Yugoslav media and political system. The paper then lays out the methodological framework and describes the corpus, and finally turns to the analysis and interpretation of materials.

\section{Gender, nationalism and the media in socialist and post-socialist Yugoslavia}

We can find examples of how the advent of war generates a different definition of gender identity as far back as the beginning of the 20th century (Grayzel 1999). With the justification of the need for defence, all social mechanisms are directed towards the production of a sufficient number of physically fit and resolute men who will overpower the opposing side. The role of women is reduced to the status of caring wives and fertile mothers, who will provide support to the war effort, take care of wounded soldiers, strengthen morale and produce a sufficient number of new warriors. Or, to put it differently: within the context of heightened nationalism, the woman is assigned a reproductive role, in both its biological and cultural sense (Yuval-Davis 1997). The participation of women in the public realm, as soldiers or diplomats directly involved in the war effort, is rarely recognized and quickly forgotten.

In 1990s Yugoslavia, the retreat of women from the public sphere and the heightened emphasis on the role of women as mothers and caretakers was unmistakable. To appreciate the scale of changes that took place in the former Yugoslavia in the early 1990s it is important to briefly sketch the key elements of Yugoslav gender policies before 1990. Women's emancipation was an important goal of 
communist revolutionary projects, and communist constitutions, including the Yugoslav one, all guaranteed women and men equal rights in all social spheres, including the economy, politics and culture (Łobodzińska 1995). This is not so say that communist policies actually led to a full-scale women's liberation, or that they were devoid of nationalist pressures. From the perspective of state socialism, women's emancipation was neither seen as an end in its own right, nor as a matter of free choice. Communist policies not only encouraged but demanded women's participation in the workforce and political activism, and rarely questioned the unequal distribution of labour in the private sphere, thus leaving women with the 'double burden' of both unpaid domestic work and full-time paid work outside the home (Bucur 2008). Yet despite all these drawbacks, socialist gender and family policies also brought some real improvements: women's employment rates were high, child-care costs low, and abortion rights guaranteed. However limited these advances may seem from our contemporary perspective, the advent of war was to make women's position in Yugoslav society considerably worse than it was under socialism.

The drop in the proportion of female delegates in key representative bodies speaks for itself. In 1986, the average proportion of women in republican assemblies was $19.3 \%$, while in the Federal Assembly, women accounted for $15.6 \%$ of the deputies (Ramet 1999: 102). After the first round of multiparty elections in the early 1990s, the proportion of women in republican parliaments fell to $10 \%$ in Slovenia, 4.2\% in Macedonia, 3.8\% in Croatia and 1.6\% in Serbia (Brunnbauer 2000: 156). At the same time, women were swiftly pushed into the roles of mothers and wives. In Serbia, the proliferation of sexist attitudes to women was intertwined with anxieties over the growing fertility among the Albanian minority, and the proportionally lower birth-rates among ethnic Serbs (Bracewell 1996). Alarms over declining birth-rates were raised also in Slovenia, often fuelled by fears over the rising numbers of immigrants from other parts of the Yugoslav federation. In both republics, influential public figures were pushing for the introduction of legal measures that would curtail women's right to abortion or otherwise stimulate population growth (Bracewell 1996, Rener and Ule 1998). Studies examining the position of women in war-torn Yugoslavia also pointed to other processes that led to the increasing subordination and (perceived) vulnerability of women: the rise in sexual abuse and violence against women, a marked increase in risks associated with living in a conflict-ridden society etc. (Zajović 1994, Milić 1994, Papić 2005, Nikolić-Ristanović 2008). Under normal circumstances, a public discussion about violence against women could have been beneficial, but in the context of war, the publicity given to female victims 
contributed to the strengthening of gender stereotypes and to the perception of women as helpless victims (Zajović 1994).

The Yugoslav mass media were closely involved in the spreading of nationalist and sexist discourse. Political life in socialist Yugoslavia was never devoid of nationalist tensions, but the rise of nationalist elites in individual republics from the late 1980 s onwards coincided with a number of internal and external factors - including the increasingly decentralized state infrastructure, the power vacuum left after the death of the life-long Yugoslav president Josip Broz Tito, rising foreign debts, and the crumbling of the Cold War division of the world internationally - which made the political unity of the country particularly difficult to sustain (cf. Lampe 2000: 299-364). As is often the case in conflict situations (cf. Hallin 1986, Robinson 2004), the escalation of tensions narrowed the scope of legitimate controversy among political elites, and consequently among the media as well. The closing down of political debate had a knock-on effect on the existing 'hierarchy of influences' (Shoemaker and Reese 1996) that shape journalistic reporting - including individual preferences of journalists and editors, established conventions of conflict reporting, budget constraints, and the expectations of various interest groups. As the conflicts escalated, the disparate interests of various stakeholders gave way to a singular national interest. In some cases, this tightening encountered little resistance; journalists and editors willingly abandoned the professional conventions of analytical and balanced coverage, and adopted a patriotic stance. In other instances, political elites and military elites resorted to more or less direct forms of censorship, pressure and even direct threats (e.g. Thompson 1999, Kurspahić 2003). The peculiarities of the Yugoslav media system and journalistic culture - the near absence of pan-Yugoslav media, and strong ties with the increasingly nationally-minded elites - also contributed to these developments, and facilitated the spreading of nationalist hostilities (e.g. Snyder 2002, Thompson 1999).

These constraints certainly contributed to the proliferation of nationalist discourse and sexist attitudes in the media, and much of the material reviewed in our study confirms that. Nonetheless, mainstream media were not entirely devoid of ambiguity and multivocality. Let us immediately clarify that this multivocality did not necessarily entail anti-nationalist and anti-sexist positions. In contrast to some of the early treatments of multivocality or polysemy in media texts (e.g. Newcomb 1984, Fiske 1987) we do not posit a necessary link between multivocality and resistance. Rather, we argue that the multivocality of media texts can fulfil a range of different functions vis-à-vis established relationships of power: it can provide space for a resistive reading of a subordinate audience, but it can also be used 
strategically by a communicator to make a message more appealing to a diverse audience (cf. Checarelli 1998). If the strategic communicator is in a position of power, multivocality can therefore serve to maintain the status quo. If, in contrast, the communicator is in a subordinated position, polysemy can also be used to further change - as was the case, for instance, with social movements advocating immigrants' rights in the United States in 2006 (Edgerly et al. 2011). Given these multiple functions and uses, the existence of multivocality in war discourse should not come as a surprise.

Also important was the fact that Yugoslav wars - unlike most other conflicts examined in existing literature on war reporting - were accompanied by rapid and wide-ranging processes of change, including the introduction of multi-party democracy and market economy, and the reconfiguration of collective identities. Especially during the early phase of the wars, the shape of the future remained unclear, and that included the very shape of the political community one belonged to. This uncertainly was particularly acute in Serbia, where the political elites - as well as the media - were torn between loyalty to the Yugoslav federation and loyalty to the Serbian nation. This most likely helped make journalistic reporting more multivocal than it might have otherwise been. Another factor resisting the homogenization of discourse was the nature of television news, especially the many voices present in a bulletin - coming from presenters, journalists, and interviewees - and the diverse visual and audio codes. Even if journalists and presenters offered a fairly homogeneous interpretation of the conflict, the interviewees they turned to could adopt a different interpretation, or appropriate the narratives in distinct ways (cf. Walsh 2001 for a similar point).

\section{Methodology and sampling}

There is little doubt that critical discourse analysis (CDA) is particularly well suited for a study such as ours. The assumption underpinning this type of analysis is that discourse is involved in the construction of social situations, identities and relationships between individuals (Fairclough 1985). Social inequalities are thus bound to be visible also in the realm of discourse. For instance, discrimination against women in public life, which constitutes one of the aspects of social inequality often studied discursively (Van Dijk 1993) is reflected in the restricted access women have to communication channels, in the treatment of women as less credible speakers, in the consistent use of membership categories that highlight women's role in the private sphere (e.g. wife, mother) etc. (Fowler 1991, Wodak 1999). However, if the application of CDA to a multimodal and multilayered text such as a 
television news bulletin brings with it particular problems: Which of the many voices present in a bulletin - coming from presenters, journalists, interviewees - should we focus on? How should we approach the relationship between visual and textual elements?

A useful distinction is one customarily drawn between institutional and accessed voices, i.e. the statements of those speakers who speak on behalf of the organization producing the bulletin - news anchors, news readers, journalists and correspondents - and the statements of external sources contributing their views to the broadcast - e.g. interviewees or public speakers (Selby and Cowdery 1995: 129). The line between the two is of course fuzzy. All accessed voices, simply by the virtue of being included in the broadcast, already bear an imprint of the institution itself. In addition, they are also influenced by the nature of questions posed, and by subsequent editing and journalists' comments. On the other hand, news anchors and journalists may include direct quotes from interviewees in their own commentary. Nevertheless, for the purpose of our study, this distinction proved worthwhile: the analysis revealed significant discrepancies between discursive constructions of nationhood and womanhood present in journalistic speech, and those apparent in statements by various female individuals interviewed.

The analysis is divided into two layers. The first layer involves reviewing all news bulletins included in the sample, identifying all sections (i.e. news reports) dealing with the conflict, and isolating those in which women are mentioned or take part. We examine the topics of the news items women appear in and the social roles they are associated with, using a combination of thematic analysis and membership categorization analysis, distinguishing between categories used by the reporters and those used by women themselves. For the purpose of the second layer of analysis, we divided our sample into three sections, tied to the three types of social roles women were most often associated with: mothers, wives and professional roles. We take a closer look at each of these sample sections, paying attention to how either journalists or the interviewed women themselves discursively construct their identity - be it specifically as women, or as members of a particular national community - noting any tensions between the two, e.g. examples where female interviewees resisted the particular gendered or national identities imposed on them, or appropriated them in distinct ways. Due to the limitations of space, we were not able to include a consideration of visual footage. 
Our sample includes all prime-time TV news bulletins broadcast in the period from June 17 to July 6, 1991. Materials come from two TV stations, located in two different Yugoslav republics: TV Ljubljana in the Republic of Slovenia (TVL) and TV Belgrade (TVB) in the Republic of Serbia. The chosen period covers the military conflict between the Yugoslav People's Army (YPA) and the Territorial Defence units of Slovenia, which started on June 27, the day when Slovenia (along with Croatia) declared its independence. The declaration prompted the YPA to make an attempt to keep the country together and maintain federal control over Slovenia's borders, while the Slovenian government mobilized its Territorial Defence units, arguing that the Yugoslav army intervention is in fact a hostile attack of a foreign army on a sovereign state. After international intervention a cease-fire was agreed on 7 July, and following prolonged negotiations the YPA withdrew from Slovenia, while the epicentre of the conflict moved into Croatia and soon after that into Bosnia. In addition to the ten days-coverage of the conflict itself, we also examined the news programmes broadcast during the ten days preceding the conflict, when the political and military apparatuses in both republics were gearing up for a potential military confrontation.

At the time, the ruling political elites in Slovenia and Serbia disagreed over the course of development Yugoslavia should take in the future. While the Slovenian leadership pushed for Slovenia's independence, the Serbian leadership was largely in favour of maintaining the Yugoslav federation as a single political unit. Mainstream media outlets in each of the republics followed a similar pattern. By drawing on samples of television from these two republics, we are therefore able to show how similar gendered identities (e.g. women as mothers) were incorporated into two distinct national narratives: one pro-Yugoslav, the other pro-Slovenian. These, however, were not the only narratives visible in the materials: the interviewees occasionally gave voice to a third, pro-Serbian national narrative, or refused to accept the narrative offered to them.

\section{Analysis and discussion}

The sample of news reports from TV Belgrade contains 294 news items concerned with the political and military conflict in Slovenia. Of these, women are mentioned as participants or are directly present in only twelve or just over $4 \%$ of all reports dealing with the conflict. The majority of these twelve reports deal with the protests by the parents of conscripts who happened to be serving the Yugoslav People's Army in the war regions of Slovenia. Another prominent group of reports contains 
interviews with wives of army officers stationed in Slovenia, forced to leave their homes after the start of the conflicts. Evidently, women appeared exclusively in relation to topics associated with the private sphere, i.e. either as mothers or wives. Only one report features a woman in a professional capacity - a member of the Slovenian parliament.

This is confirmed by the analysis of membership categories used to refer to women, either by the reporters or by women participants themselves. In almost all cases where women are identified by reporters, membership categories associated with the private sphere are used ('mother', 'wife', (parent'), sometimes in combination with qualifications that point to the subordinate and passive position of the women in question (e.g. 'unemployed wife'). The only two exceptions are the report that includes a statement by a member of the Slovenian parliament, who is identified as such, and a report containing a set of comments by the inhabitants of Brussels, including a woman who identifies herself as a representative of 'the citizens'. Equally telling is the fact that only one of the reports concerned with the parents' protest in the Serbian parliament used the category 'fathers', even though the visual footage of the event often included images of male protesters. Direct speech by women is found in eight reports, and in all but one case, women present themselves on the basis of their family status, as 'mothers' and 'wives'. Such self-categorization situates them squarely into the private sphere.

The analysis of news bulletins broadcast in the same period by TV Ljubljana produced similar results. Out of a total of 184 television reports concerned with the conflict, women appeared as participants or subjects in only nine (5\%) of all reports, which is only marginally more often than in the case of TV Belgrade. Of the nine reports with female participants, six were dedicated to parents' protests and their visits to conscripts stationed in Slovenia, and were thus thematically similar to the ones produced by TV Belgrade. The remaining three featured women in professional roles, though two of these were women in typically 'feminine' professions: a nurse and a teacher. A compatible result was reached using membership categorization analysis. As with TV Belgrade, categories describing family status prevailed, but in this case, they were most often (fifteen cases, of which thirteen in journalists' contributions) not gender specific - namely, women were described generically as 'parents'. Genderspecific categories and categories in feminine gender included 'mummy' (twice), 'little girl', 'female patient' and 'group of women' (six cases, of which three in journalists' contributions). To sum up, despite some differences, the coverage of the conflict provided by both televisions instituted a sharp division between private and public domains, and associated the latter primarily with men. 
In the remainder of our analysis, we take a closer look at the news reports, and investigate the ways in which the gendered structures of discourse became interlocked with nationalist discourse. This part of analysis is divided into three thematic blocks, each tied to one of the key social roles women were associated with in the reports.

\section{Women as mothers}

The string of events involving women as mothers, embraced with noticeable publicity by both media companies, was tied to the anti-war movement initiated by parents whose sons were undergoing the obligatory military training while the war was flaring up. Similar protests were held in several republics at the time and were accompanied by messages of peace asking for the complete cessation of armed conflict throughout the country (Žarkov 2007). During the first military clashes in Slovenia, two of such events caught the attention of the media. The first was the incident in the Serbian parliament, when a group of protesters inadvertently forced their way into the parliamentary building. The second was the parents' visit to their sons-soldiers stationed in Slovenia. These two events irrefutably blew apart the picture of a general social consensus with regard to the military action in Slovenia, which prevailed in the Serbian media mainstream up until then. Throughout the period examined in our study, TV Belgrade's journalists were mostly siding with federal institutions (including the army) and identified themselves with the broader Yugoslav self - a tendency examined in detail in a separate study (Mihelj et al. 2009b). Yet the protests made it clear that the Serbian population did not regard the intervention in Slovenia as entirely legitimate. It is instructive to examine how the two television stations reacted to these two events, how the reporters negotiated the identities of female protesters and incorporated them into disparate narratives, and how the women themselves, when given a chance, reacted to the identities and narratives imposed by reporters.

TV Belgrade mostly presented the incident in the parliament as an emotion-driven, chaotic disturbance, caused by maternal anxiety rather than as general national dissatisfaction. This framing was in line with the prevailing pro-Yugoslav stance towards the conflict among TV Belgrade's reporters, and helped discredit protesters' claims. Such an interpretation was partly visible already in the very first report on this event: 
02/07/1991. TVB, Reporter: In an unprecedented manner, the session of the Serbian parliament was interrupted today [...] Around 50 parents of soldiers from the whole of Serbia came to demand the return of their children from Slovenia. Some of them [...] demanded the Assembly to guarantee the return of children to their homes; failing that, they will attack the barracks in Serbia and keep the soldiers from Slovenia and Croatia as hostages. Immediately after that, after they entered the assembly room, the session was suspended. The blockade is ongoing and it is unclear for how long it will last. [...] Some deputies tried to impose some order onto what was happening, mostly unsuccessfully.

As evident from the excerpt, the reporter presented the event and the key participants parents - in rather negative terms, constantly emphasizing the chaotic nature of the event ('blockade', 'it is unclear for how long it will last') and contrasting it with the attempts by the deputies who were trying to 'impose some order'. The rest of the reporter's commentary unfolded in the same manner, emphasizing the unruliness of the protest and the inconsistent nature of parents' demands. In subsequent news reports provided by TV Belgrade, as well as in later media reports on the parents' protests in the Serbian media more generally, protesters were increasingly often identified as 'mothers', thus gradually building a traditional gendered representation of these events. Arguably, the presence of men in these allegedly emotion-driven events was inconsistent with the traditional understanding of masculinity and femininity that became prevalent during the war, and was thus downplayed in verbal representations.

TV Ljubljana interpreted the incident in the Serbian parliament in a considerably different manner, as a legitimate protest by parents, directed first of all at the Yugoslav army:

02/07/1991. TVL, Reporter: Then the parents of soldiers who were serving their military duty in Slovenia broke into the Serbian parliament and expressed considerable bitterness about everything that was happening at that moment in the army, which was playing around with their innocent children [nedolžnimi otroki].

The report presents the event as fairly aggressive ('broke in') and emotional ('parents ... expressed considerable bitterness') yet also rather unambiguous in its main intent (protection of soldiers) and target (the army). By positioning parents and conscripts as victims of the Yugoslav army, and by 
describing conscripts as 'innocent children', the reporter uses the incident in the Serbian parliament to underscore the cruel and merciless nature of the enemy army. Such a strategy is in line with the national narrative promoted by TV Ljubljana at the time, according to which the Yugoslav People's Army was the major enemy (cf. Mihelj et al. 2009b). In the commentary that follows, the reporter continues to build a negative image of the enemy, and even interprets the parents' protest as a trigger that will eventually lead to the enemy's demise. Yet in contrast to the first excerpt, attention now gradually shifts away from the army to a different enemy, namely the National Parliament of the Republic of Serbia:

02/07/1991. TVL, Reporter: Today, in the Serbian Parliament, the soldiers' parents demanded that their sons return to their barracks within 24 hours. The government must retreat, and General Kadijević must immediately justify his actions. They also demanded the arming of the Serbian National Guard, which should be deployed to save the soldiers in Slovenia, because the Yugoslav People's Army had betrayed them. If we add to this their request to immediately form a multi-party parliament, it can be said that today's events in the Serbian Parliament could also very likely mean its collapse.

Evidently, the Yugoslav People's Army turns out to be not only the enemy of Slovenia, but also the enemy of the Serbian people, and more specifically Serbian parents - an enemy that 'betrayed them', is exposing their sons to unnecessary risks, and stands in the way of a 'multi-party parliament'. 'TV Ljubljana thus makes an attempt to express solidarity with Serbian parents and their (perceived) aims, and uses this to further underscore the negative image of national enemies.

However, not all of the reports about parents' protests were equally monovocal. In many cases, speeches and statements given by women protesters diverged from the framings provided by the reporters. Of particular interest here is the speech by Nena Kunijević, who emerged as an unofficial leader of parents' protests and whose address to the Serbian parliament featured prominently in the bulletins by both televisions. The following excerpt sums up the main points of her address:

02/07/1991. TVB, Nena Kunijević: I am not in any political party. Before anything else I am a mother. I am a Serb. I have four children. I have two who I don't know whether they are alive or not and I am proud of them, but I shall not allow their lives to be all the same to 
you. What has Ante Marković got to do with me? I voted for you and I expect you to take responsibility, not Ante Marković.

Kunijević identifies herself as a mother and as a Serb, thus simultaneously associating herself with the private sphere and with the imagined national community of Serbs. She underscores the legitimacy of her position by presenting it as something that precedes everything else, including party affiliations. It is from this position that she voices her protest; as a Serbian woman and mother, she sees no need for the military intervention in Slovenia - a republic where the presence of Serbs was rather limited - and is not prepared to put her sons' lives at risk for it. This is further underscored by her disparaging attitude towards Ante Marković, Yugoslavia's Prime Minister at the time, which makes clear that as a Serbian woman, she feels no connection to federal authorities, and instead expects the delegates of the Serbian assembly ('you') to take responsibility for her children. While Kunijević accepts the gender identity ascribed to her by TV Belgrade's journalists (mother, parent), she does not accept the collective identification with the Yugoslav self. From her perspective, Yugoslav interests, embodied in the actions of Marković and the army, have nothing to do with her own interests. Evidently, Kunijević is not challenging war as such, but rather protests against this particular war, because it is not in her national interest (see also Žarkov 2007 for a similar conclusion). Other women's statements included in the bulletins are likewise hostile to the Yugoslav People's Army and state institutions, and express similar doubts about the justification for this particular war (but not necessarily war in general). As Kunijević, they are unambiguous about their position as mothers, but reject the association with the Yugoslav self and Yugoslav institutions.

Another example of multivocality is found in reports about the parents' visit to the barracks in Slovenia. Both television companies present the event as a dramatic, emotional reunion between mothers (or parents) and sons after weeks of anxiety and fear, but interpret their significance in divergent ways, following the plot of two distinct national narratives - a pro-Yugoslav one in the case of TV Belgrade, a pro-Slovenian one in the case of TV Ljubljana. TV Belgrade's reporters give no explicit indication of who might be responsible for the anxiety suffered by parents. They present the visit to the barracks as an exceptional gesture, which does not challenge the loyalty of the parents and soldiers to the federal state and has nothing to do with parents' demands for the return of soldiers' to Serbia. The following excerpt is a case in point: 
04/07/1991. TVB, Reporter: ...The soldiers are feeling fine and are in a very good mood. They don't want to go home, because, as they put it, their place is here, with their mates.

Later in the same report, an exchange between the reporter and a group of soldiers stationed in Slovenia with their mothers is shown, during which the disjunction between the journalistic narrative and the parents' narrative becomes blatantly obvious:

TVB, Reporter: What's it like being an older soldier these days?

Soldier 1: What can I say? You can see for yourself. It's not easy.

Reporter: This is your mother, I presume.

Mother: Yes.

Reporter: You've come here to see your son.

Mother: [incomprehensible]...to say that it's awful... [through tears, incomprehensible]

Soldier 1: Well, it's not exactly easy, but the army is the army.

Reporter: Perhaps some parents have mistakenly come to take their children home. Is that what you feel as well?

Soldier 1: No. I have 50 days of service left and will serve them duly.

Soldier 2: If I endured all of this I will endure also these 50 days.

Soldier 3: We are all here. We take care of each other, as you say, we watch our backs and so on.

Reporter: Your parents came, most with the intention to bring you home.

Soldier 1: Well this is generally, erm, not generally but definitely not an option, because we are all as one. We cannot do one without the other. There is no going home until all of this is over and until Yugoslavia is not as it should be.

The exchange establishes a clear contrast between the emotional, teary and helpless mothervictim, whose words are unclear and who is evidently unable to behave rationally, and the resolute unity of soldiers who do not want to return back home with their parents until they serve their duty and 'until Yugoslavia is not as it should be'. The reporter sides with the soldiers - and, through that, with the proYugoslav narrative - and makes clear that the parents who demanded the return of their children were evidently 'mistaken'. Nonetheless, the presence of the teary mother serves as a reminder that a segment of the population was not prepared to endorse the pro-Yugoslav perspective. 
In contrast, TV Ljubljana was attempting to fit the suffering of Serbian parents into an overarching pro-Slovenian narrative, organized around the contrast between innocent Slovenians (now joined by innocent Serbian parents and their children) and the cruel, merciless Yugoslav People's Army. Yet while some Serbian parents were willing to display their anxiety and then joy in front of the cameras, explaining how relieved they were at meeting their children again and seeing they are alive and well, others were not particularly eager to toe the journalist's line:

04/07/1991. TVL, Reporter: Excuse me, could I ask you where you came from?

Woman: [grudgingly] From Yugoslavia.

Reporter: Did anyone promise you that they will let your children leave the barracks?

Woman: [grudgingly] Did anyone promise me?

Reporter: Yes.

Woman: [grudgingly] We came to visit them. [emphasis on visit]

Man: The darkest and ugliest manipulation with children, for sure.

Reporter: Why do you think it came to this?

Man: Not politics, because of political manipulants of the worst kind. [Then turns away from the camera and continues his way, and shouts loudly:] Fuck off!

Evidently, the two interviewees were reluctant to engage with the journalist, let alone single out the army as the party to blame for their suffering. Their behaviour challenges the preferred narrative fostered by TV Ljubljana, almost to the point of treating the journalist herself as one of those 'political manipulants' responsible for their suffering.

How can we interpret these diverse examples of multivocality, and, most importantly, how do they relate to established power relationships? Should we see them as indicative of anti-nationalist resistance on the side of the interviewees, or as examples of strategic polysemy adopted by the television companies themselves? In the case of women protesters in the Serbian parliament, given voice in TVB's coverage, there is little trace of anti-nationalist resistance. Instead of rejecting nationalist rhetoric as such, the interviewees merely counter one form of nationalism (Yugoslav) with another (Serbian). By incorporating such voices, TV Belgrade could remain loyal to the official pro-Yugoslav line, while also signalling its sympathy for the pro-Serbian perspective. Indeed, after the cessation of 
hostilities in July 1991, the perspective promoted by parents such as Kunijević prevailed, and preventing Slovenia's secession was no longer seen as a strategic priority. The second and third examples are less straight-forward, because the parents featured do not offer any well-articulated counter-narrative. While it may be possible that their resistance invited anti-nationalist readings on the side of the audience, it is equally possible that they provoked a nationalist reading. For instance, in the last example, the presence of hostile Serbian parents, swearing in front of the camera, could have fed into the anti-Serbian sentiments that were present at the time among a substantial segment of the Slovenian population. In sum, the presence of multivocality in the war should therefore not be interpreted merely as proof of the failure of official narratives, but rather as evidence of their malleability.

\section{Women as wives}

The second social role frequently ascribed to women in our sample of news reports was the role of the wife. This role was present almost exclusively in TV Belgrade's coverage, and mostly appeared in the context of interviews with women married to members of the Yugoslav People's Army stationed in Slovenia, who were told to leave their homes and move to Serbia. While being interviewed, most of these women accepted the identity ascribed to them by the media, and performed it in accordance with social expectations, emphasizing above all their devotion to their husbands and children and loyalty to their family, as if no other life existed beyond that. The following excerpt is taken from an interview with a group of women who just came to Serbia from Maribor, the second largest city in Slovenia. The interview was introduced immediately after a report describing the plight of customs officers employed by the federal authorities to work at the Yugoslav border in Slovenia. Similarly as the customs officers, the Yugoslav army officers and their wives were presented as victims of the conflict and targets of hostility from Slovenian authorities, and most of the interviewed women-wives complied with this narrative, as in the following example:

02/07/1991. TVB, Woman 1: ... I'm an officer's wife, the mother of two children and yesterday we were informed that we have to leave Maribor and, by whatever means we can, go to Belgrade. It was difficult, but we had to leave. We knew that there were very few officers remaining in the Army and that they were without food. Somehow we managed to bring them a couple of sandwiches, some cigarettes. They grabbed that and told us to leave. 
The interviewee introduces herself in a manner fully compliant with traditional gender expectations, as well as with the victimhood narrative established by the reporter. She describes herself as an 'officer's wife' and a 'mother of two children', thereby defining her own identity solely in relation to her husband and her children. Her mention of food and cigarettes supplied to the officers makes clear that her own life is fully subordinated to the life of her husband and, through him, the army. By emphasizing how 'difficult' it was to leave and pointing out that officers were 'without food', as well as by mentioning, later on in the same reply, her son's sickness and headache, she also establishes herself as a victim, and enlists her whole family in the same victim-status. Other women interviewed followed a similar pattern, and all were also visibly distressed. The insecurity, tears and feelings of confusion expressed during the interview offer the expected spectacle of distraught women-victims, which fits into the traditional, gendered war discourse. The women appear weak, helpless, and entirely dependent on men, and comply fully with the victimization model that was gaining ground at the time (Zajović 1994).

An exception is the youngest interviewee from the group, whose identity remains unclear but who is most likely a daughter of Serbian parents born in Slovenia:

02/07/1991. TVB, Woman 4: ... I had to escape because of the pressure. I was born in Maribor, all my friends are there, I went to school there, and to university, and I can tell you that some of my friends didn't give in to the pressure. They called me at home and gave me their support. They told me that friendship comes first, and politics after that, and it doesn't matter what some people say - not many people chuck away friendship. When all this is over, we plan to have a picnic [in tears] to drive out all this anger inside us.

The speaker does not identify herself in traditional gendered terms, but instead mentions her studies and her friends in Slovenia. In doing so, she also challenges the prevailing nationalist narrative, and instead emphasizes the support she received from her friends in Slovenia, suggesting that friendship is capable of surpassing political and national divisions. In contrast to examples of multivocality discussed earlier, this case - unique in the sample we examined - provides an example where multivocality goes hand-in-hand with resistance.

\section{Women in professional roles}


In news reports studied, we also identified five items featuring women who speak from the position of their profession. Four of them were found in TV Ljubljana's coverage, and one in TV Belgrade's. Unlike most of the women who are described as mothers of wives, the women appearing in these items are identified by name, do not show any signs of emotional distress, and are presented as active participants of the war rather than its victims. Yet a closer look at the nature of their professions and content of their statements reveals that these women' actions are limited to areas traditionally associated with women: education, healthcare, and family-related policy issues. The first of these cases involves a brief statement by a female teacher who informs parents that their children who are on a summer school trip are safe. The second example is a brief interview with a female nurse working in a hospital that had been evacuated to the basement:

02/07/1991. TVL, Reporter: We are in the basement of the gynaecology unit, where the maternity unit has been relocated to as well. Life is being created continuously, regardless of the circumstances. We also see the subterranean shelter, which appears much friendlier than others already at first sight.

Hedvika Skraban, senior nurse: Unfortunately, today the shelter serves its intended function. The evacuation of patients proceeded in a peaceful manner, we have several rooms here.

Reporter: Did you have any births?

Hedvika Skraban: Yes, we had a birth on the first day, here is the record I am keeping, which will stay here as a souvenir. We also had a birth on the 30 June, a girl was born, it was the mother's second birth, we do not have any further details yet, but we will keep updating the record regularly.

The nurse is treated as an authoritative source of information, and as evident from her statements, her main aim is to emphasize the peaceful and orderly nature of the evacuation and subsequent events in the maternity unit. Yet at the same time, her authority is limited to the traditionally feminine realm - namely childbearing and childrearing - and only reinforces the traditional gendered division of social roles. The interview forms part of a longer string of brief exchanges with personnel and patients at the hospital, which follow the same pattern as the above-quoted passage and serve to illustrate the effect war conditions on the life in the hospital, but also provide assurance that 
things are kept under control despite the chaos of war presented in other reports. The reporter's introduction to the maternity unit incorporates the nurse's statement into a larger narrative about the perseverance of human life. Arguably, the life created at the hospital functions as a symbol of Slovenian national reproduction and survival, despite the hardships of war. At the same time, the poignant image of the maternity ward in war conditions, in which the lives of newborn babies are directly at risk, also helps underscore the image of the Yugoslav People's Army as a cruel adversary, willing to endanger the lives of even the most innocent members of the civilian population. TV Belgrade's portrayals of womenwives and TV Slovenia's representations of women in professional positions thus serve the same basic aim: they both use stereotypical images of femininity to enhance the contrast between 'our' innocence and victimhood and 'their' cruelty and aggression.

\section{Conclusion}

Two major conclusions can be drawn on the basis of our case study. First, our analysis confirms that war reporting is characterized by a confluence of nationalist and sexist discourse. This discursive universe restricts the lives of women to a rather limited set of roles tied to the private domain - caring mothers, loving wives, dutiful daughters and sisters - and expects them to reproduce the nation both biologically and culturally. Indeed, the television coverage of the military conflict between the Yugoslav People's Army and the Slovenian Territorial Defence in 1991 was almost devoid of female actors, let alone women who would appear in professional, public capacity. Out of all news reports dedicated to the conflict over the course of 20 days, women appear as participants in fewer than $5 \%$ of them, and of these, the vast majority are identified as wives and mothers, whose main concerns are achieving biological reproduction and protection of their families and their nation. Often, women-wives and women-mothers are presented in moments of emotional disorder and assigned the role of victim. Even the few women who are acting in professional capacity are engaged in activities that are traditionally perceived as female. In sum, virtually all representations of women in our sample thus contribute to the discourse that expected women in war-torn Yugoslavia to return to their traditional roles, and serve their nations primarily as mothers and wives (cf. Nikolić-Ristanović 2008).

Second, we have also shown how women's gendered identities were incorporated into disparate national narratives - a pro-Yugoslav narrative fostered by TV Belgrade on the one hand, and a pro- 
Slovenian narrative fostered by TV Ljubljana on the other hand. Yet our analysis also demonstrated that not all of the women present on television screens were equally eager to embrace the identities and narratives imposed on them by the media. While mostly accepting the traditional identities of mothers and wives, some of the interviewees resisted the national narratives fostered by the reporters, or even explicitly supported alternative narratives. We have also argued, however, that this multiplicity of voices and narratives should not be interpreted as proof of the failure of official narratives, or of the interviewee's ability to resist nationalist and sexist narratives. While we did find some evidence of such resistance, most cases of multivocality either involved no clear alternative, or offered an alternative that was equally nationalist and/or sexist as the officially endorsed narrative. Arguably, such forms of multivocality allowed the media to retain a fairly ambiguous position and appeal to viewers - including political elites - with disparate attitudes to the event in question.

Given the size of our sample it is of course difficult to draw any firm conclusions about how widespread these different forms of multivocality might be in war discourse more generally. It is possible that the nature of the case study in question made the mainstream media more open to multiple voices than they would have otherwise been. The conflict examined here occurred at a point when the future of the Yugoslav federation was rather unclear, and was accompanied by large-scale political, economic and cultural changes. Arguably, multivocality allowed media institutions to adapt swiftly to the changing political and ideological landscapes.

\section{BIBLIOGRAPHY}

Bracewell, W. (1996) 'Women, Motherhood, and Contemporary Serbian Nationalism', Women's Studies International Forum 19(1/2): 25-33.

Brunnbauer, U. (2000) 'From Equality without Democracy to Democracy without Equality? Women and Transition in Southeast Europe', South-East Europe Review 3: 151-68.

Bucur, M. (2008) 'An Archipelago of Stories: Gender History in Eastern Europe', American Historical Review 113(5): 1375-89.

Bugarski, R. (1997) Jezik od mira do rata. Belgrade: Čigoja štampa.

Ceccarelli, L. (1998) 'Polysemy: Meanings in Rhetorical Criticism', Quarterly Journal of Speech 84(4): 395415.

Edgerly, L., A. Toft, and M.L. Veden (2011) 'Social Movements, Political Goals and the May 1 Marches: Communicating Protest in Polysemous Media Environments', The International Journal of Press and Politics 20(10): 1-21. 
Fairclough, N. (1985) 'Critical and Descriptive Goals in Discourse Analysis', Journal of Pragmatics 9: 739763.

Fiske, J. (1987) 'Television: Polysemy and Popularity', Critical Studies in Mass Communication 3(4): 391408.

Fowler R. (1991) Language in the News. London: Routledge.

Grayzel, S. R. (1999) Women's Identities at War: Gender, Motherhood and Politics in Britain and France during the First World War. Chapel Hill, NC: The University of North Carolina Press.

Hallin, D. (1986) The 'Uncensored War': The Media and Vietnam. Berkeley, CA: University of California Press.

Kurspahić, K. (2003) Prime Time Crime: Balkan Media in War and Peace. Washington, DC: US Institute of Peace.

Lampe, J. (2000) Yugoslavia s History: Twice there was a Country. Cambridge: Cambridge University Press.

Łobodzińska, B. (ed) (1995) Family, Women and Employment in Central-Eastern Europe. Westport, CT: Greenwood Press.

Milić, A. (1994) Žene, politika, porodica. Beograd: Institut za političke studije.

Mihelj, S., V. Bajt and M. Pankov (2009a) 'Television News, Narrative Conventions and National Imagination', Discourse and Communication 3 (1): 57-78.

Mihelj, S., V. Bajt and M. Pankov (2009b) 'Reorganising the Identification Matrix: Televisual Construction of Identity in the Early Phase of Yugoslav Disintegration', pp. 39-59 in P. Kølsto (ed.) Media Discourse and the Yugoslav Conflicts: Representations of Self and Other. Aldershot: Ashgate.

Newcomb, H. M. (1984) 'On the Dialogic Aspects of Mass Communication', Critical Studies in Mass Communication 1(1): 34-50.

Nikolić-Ristanović, V. (2008) Preživeti tranziciju. Beograd: Službeni glasnik.

Papić, Ž. (2005) 'Nationalism, Patriarchy and War in Ex-Yugoslavia', pp. 99-124 in D. Johnson (ed.) Gender, Nation, Identity. Belgrade: Women in Black.

Prividera, L. C. and J.W. Howard III (2006) 'Masculinity, Whiteness, and the Warrior Hero: Perpetuating the Strategic Rhetoric of U.S. Nationalism and the Marginalization of Women', Women and Language 29(2): 29-37.

Ramet, S. (1999) 'In Tito's Time', pp. 89-105 in S. Ramet (ed.) Gender Politics in the Western Balkans: Women, Society and Politics. University Park, PA: Pennsylvania University Press.

Rener, T. and M. Ule (1998) 'Back to the Future: Nationalism and Gender in Post-socialist Societies', pp. 120-132 in R. Wilford and R. L. Miller (eds.) Women, Ethnicity and Nationalism: The Politics of Transition. London: Routledge. 
Robinson, P. (2004) 'Researching Media-State Relations and Twenty-first Century Wars', pp. 96-112 in S. Allan and B. Zelizer (eds.) Reporting War: Journalism in Wartime. London: Routledge.

Selby, K. and R. Cowdery (1995) How to Study Television. London: Macmillan.

Shoemaker, P.J and S.D. Reese (1996) Mediating the Message: Theories of Influences on Mass Media Content. White Plains, NY: Longman.

Snyder, J. (2000) From Voting to Violence: Democratization and Nationalist Conflict. New York: WW Norton.

Thompson, M. (1999) Forging War: The Media in Serbia, Croatia and Bosnia-Herzegovina, 2nd eds. Luton: University of Luton Press.

Van Dijk, T.A (1993) 'Principles of Critical Discourse Analysis', Discourse \& Society 4(2), 249-283.

Van Dijk, T.A (2006) 'Discourse and Manipulation', Discourse \& Society, 17(3): 356-83.

Walsh, C. (2001) Gender and Discourse. London: Longman.

Wodak, R. (ed.) (1997) Gender \& Discourse. London: Sage.

Yuval-Davis, N. (1997) Gender and Nation. Buckingham: Palgrave.

Zajović, S. (1994) 'Rađanje, nacionalizam i rat', Žene protiv rata 1. Belgrade: Žene u crnom.

Žarkov, D. (2007) The Body of War. Durham, NC: Duke University Press. 


\section{Notes}

${ }^{1}$ The first multi-party parliamentary elections in Serbia were held in 1990, but their legitimacy was disputed. The former Communist Party, now renamed into the Socialist Party of Serbia and led by Slobodan Milošević, won the vast majority of seats, and due to that, the Slovenian political and media mainstream refused to treat the Serbian parliament as a multi-party parliament. 